\title{
SOCIO-ECONOMIC, FARM AND TECHNOLOGICAL CHARACTERISTICS OF THE PERI-URBAN SMALL AND MARGINAL DAIRY FARMERS OF CHITTAGONG METRO AREA, BANGLADESH
}

\author{
S.M.M.A. Dipu*, M.R. Begum and S. Sultana \\ Department of Agricultural Economics and Social Sciences, Chittagong Veterinary and \\ Animal Sciences University, Bangladesh, Chittagong, Bangladesh
}

\begin{abstract}
The paper depicted the salient features of the socio-economic, farm and technological background and the existing problems of the peri-urban small and marginal dairy farmers of Chittagong Metro Area (CMA), Bangladesh. Data were collected using a pre-tested structured questionnaire. Snowball sampling method was used to gather socioeconomic, farm and technological data. Both descriptive statistics and mathematical analyses were used for analyzing the data. The study finds the peri-urban small and marginal dairy farmers are not fully dependent on dairy farming for income and young people are less interested in dairy farming as well. Better education status, less profitability, unfair and unstable price, etc. might be the reasons behind this circumstance. Though the farmers get lesser price for milk, the milk price is higher in urban market. Interestingly, $62.7 \%, 52.9 \%$ and $51.0 \%$ of the farmer families have smartphone, facebook and internet users respectively. Based on the findings, the study recommends that technology-based market linkage could be created by any government/non-government development partner between the cluster-based farmers' group and the urban consumers for ensuring fair price for milk.
\end{abstract}

Keywords: Peri-urban, Small and Marginal Dairy Farmers, Profitability, Socio-economy, Farm and Technology

\section{INTRODUCTION}

Dairying is very common income source in rural and peri-urban areas of Bangladesh and there is prevalence of small and marginal farmers. Bangladesh Investment Development Authority (BIDA, 2010) reported that $90 \%$ of the dairy farmers have 13 cows, $6 \%$ dairy farmers have $3-10$ cows and the rest $4 \%$ dairy farmers have more than 10 cows in the country. Though dairying is a common source of income, due to

* Corresponding Author: smmadipu@cvasu.ac.bd 
the wake of price-hiking of cow's feed items, medicines and other requisite inputs, dairy farming has now become expensive for those huge numbers of poor farmers. After struggling for survival many frustrated farmers are closing their business due to financial hardship. Many of them abandoned their business due to lack of marketing facilities incurring huge financial loss (UNB, 2017).

Milk production being the key income source is true for other countries as well where it plays a crucial role to generate income and employment (Pérez Urdiales et al., 2015). Moreover, small dairy farms are considered an important way to eradicate poverty in developing counties and it acts as a great social contributor in this connection (Holloway et al., 2000; Van Schaik et al., 1996; Somda et al., 2005). In Mexico, small-scale dairy farming has been regarded as an option for rural development (Espinoza-Ortega et al., 2007). Flaten (2002) showed small dairy farms produce multiple and interconnected benefits e.g. employment and rural sustainability, food security, landscape reservation, cultural heritage and biodiversity for developed countries like Norway. Kirui and Njiraini (2013) also reported the contribution of smallholder farmers in reducing food insecurity. Again, Heady and Sonka (1974) mentioned small farms can lead to greater income generation in rural communities by stimulating more activities in the community.

In particular, small-scale marginal farmers face many constraints that obstruct them from taking advantage of market opportunities (Fischer and Qaim, 2012). Such constraints would definitely impose a greater burden on the farm families and their incomes if their problems are not addressed in policy development. Proper measures can give a way to make dairy farmers' business profitable and sustainable which will lead to an improved standard of living of those farmers (UNB, 2016). Otherwise, transition to new economic sectors and activities may swap dairy farming activities (Flaten, 2002) and that is why policy for small and marginal dairy farmers needs to be fine-tuned to improve the situation. Such policy fine-tuning requires sufficient information regarding those farmers. A national dairy performance profile was developed considering the performance of the smallholder dairy production system and backward and forward supports and existing development programs and policies (Huque, 2011). Another study explored the small-scale dairy producers in Barura Upazilla of Comilla, Bangladesh to determine the role of small scale dairy cattle farming in improving their life styles also to identify the problems faced by them (Uddin et al., 2012). Quddus (2018) discussed the factors affecting dairy income and labor utilization, compared the performance of crossbred and indigenous cows, and reported the restraints of the smallholder dairy farmers of Jessore, Sherpur, Gazipur, Bogura and Mymensing. Household and farm economics of smallholding dairy farmers in Sirajganj was analyzed and cost of milk production was obtained to measure their vulnerability to international market in a report of Food and Agriculture Organization (Hemme et al., 2004). In another study, the impact of government subsidy program on small scale farm characteristics and farm financial performance was examined (Kabir and Talukder, 1999). Espinoza-Ortega et al. 
(2007) found in a study in central Mexico that small-scale dairy farms are heterogeneous and the farms should not be treated as equal while developing the policy. Hence, based on the above literature review, there are still scopes for studies on small scale marginal farmers across different socio-economic and agro-ecological zonation in Bangladesh. The present study depicts the salient features regarding the socio-economic, farm and technological aspects of the peri-urban small and marginal dairy farmers, who have 1 to 10 cattle, of Chittagong Metro Area (CMA). It also aims to report the specific problems and also to pin-point the root causes of the problems faced by those farmers in the study area.

\section{METHODOLOGY}

\section{Study area and duration}

This is a cross-sectional descriptive study where the data were collected during October 2017 to December 2017 from field visits in the ten adjacent villages (periurban) to CMA (Gizaw et al., 2017), the second biggest metro area of Bangladesh. These ten villages mostly fit the per-urban villages of Chittagong Metro City as they are the only villages situated at the very entrance of the City namely Chikondondi, Shikarpur, Burirchor (Hathazari Upazilla); Urkirchar, Noapara (Raojan Upazilla); Gomdandi (Boalkhali Upazilla); Char Pathorghata, Shikalbaha, Kolagaon (Patiya Upazilla) and Salimpur (Sitakund Upazilla).

\section{Sample size}

Snowball sampling method was used to collect data from four to seven marginal dairy farmers from each village totaling a sample size of 51 out of 560 farmers ( $9.11 \%$ of the population). There was no farmers' database available and hence the population size was determined by personal observation and discussion with the local vets, Upazilla Veterinary Surgeons and Livestock Officers. In this particular study, dairy farmers having 1 to 10 cattle was considered small and marginal dairy farmers' as the classification of BIDA, 2010.

\section{Data collection}

A pre-tested structured questionnaire was used to gather farm data as well as demographic, socio-economic and technological data of the farmers. Extensive probing technique was used to collect their financial data as none of the farmers are used to keeping book of records. However, to buy the time of the farmers, they were given token gifts. Before starting the survey, they were given brief idea about the study. Data regarding problems faced by the farmers and the reasons for unfair price was collected in 5-point Likert scale where 1, 2, 3, 4 and 5 denote to Strongly Disagree, Disagree, Neutral, Agree and Strongly Agree respectively. The information provided by the farmers were put instantly on the survey sheet and later on the data were entered in the excel sheet for mean calculation. Besides, local and near-by town markets were also visited during the study time to collect market information. 


\section{Analytical Technique and Tool}

Most of the variables were chosen for socio-economic and farm characterization following García, Dorward and Rehman (2012). Trending communication technology was considered while characterizing the technological background of the peri-urban marginal dairy farmers. The collected data were put in tabulation format to present the intended features of the farmers, their profitability and problems.

Regarding profitability analysis of the farms, Benefit Cost Ratio (BCR) (Meskel and Gemechu, 2017) and Return on Investment (ROI) (McDonald et al., 2013) were calculated on the basis of the simple theory of cost, revenues and investment.

$$
\mathrm{BCR}=\frac{\text { Revenues }}{\text { Costs }}
$$

Here, the costs include the last year feeding, vaccination, artificial insemination (AI), labor, damage and spoilage cost. As the farmers sell the milk mostly in the locality, there is no related marketing cost. Revenues were calculated from the last year sales of milk, cow dung and calf. The farmers cannot sell the milk all the year round. Hence, yearly milk sales were calculated on the basis of average lactation amount and period of the cows.

$$
\mathrm{ROI}=\frac{\text { Total Revenues }- \text { Total } \text { Costs }}{\text { Total Investment }} \times 100
$$

Here, total revenues minus total costs denote to the Trading Profit of the last year.

Total Investment $=$ Cost for building housing structure + cattle value + other fixed investment

To produce the information from the collected data, the descriptive statistical analysis was performed using MS Excel 2013 and SPSS 16.0.

\section{RESULTS AND DISCUSSION}

\section{Socio-economic characterization}

Eight variables have been analyzed thana-wise to characterize the socio-economic background of the peri-urban small and marginal dairy farmers of CMA (Table 1). In general, the peri-urban small and marginal dairy farmers have other income sources rather than dairy farming and majority of them are poor. According to age group analysis, the age group ' 35 years or less' has been found dominant in Patiya (53.3\%), Raojan (50.0\%) and Sitakund (42.8\%) and the age group '36 to 50 years' has been major in Boalkhali (50\%). In Hathazari, $93.4 \%$ farmers are 36+ years. Adding to that majority of the farmers $(62.7 \%)$ of the study area have farming experience of more than 15 years with an exception in Sitakund and Boalkhali. Quddus (2018) in his study on Bangladesh also found that around $56 \%$ of the famers were experienced from 11 to 20 years. It might indicate that young people are getting less interest in dairy farming and only the existing dairy farmers are doing the same only as their family tradition. 
Table 1. Socio-economic characteristics of the peri-urban marginal dairy farmers of CMA

\begin{tabular}{|c|c|c|c|c|c|c|c|}
\hline \multirow{2}{*}{\multicolumn{2}{|c|}{ Socio-economic characteristics }} & \multicolumn{6}{|c|}{ Thana } \\
\hline & & \multirow{2}{*}{\begin{tabular}{|r|}
$\begin{array}{c}\text { Sitakund } \\
\mathrm{n}=7\end{array}$ \\
$\%$ \\
\end{tabular}} & \multirow{2}{*}{\begin{tabular}{|r|}
$\begin{array}{c}\text { Hathazari } \\
\mathrm{n}=15\end{array}$ \\
$\%$ \\
\end{tabular}} & \multirow{2}{*}{\begin{tabular}{r|}
$\begin{array}{c}\text { Raojan } \\
\mathrm{n}=10\end{array}$ \\
$\%$
\end{tabular}} & \multirow{2}{*}{\begin{tabular}{|r|}
$\begin{array}{c}\text { Boalkhali } \\
\mathrm{n}=4\end{array}$ \\
$\%$ \\
\end{tabular}} & \multirow{2}{*}{\begin{tabular}{|r|}
$\begin{array}{c}\text { Patiya } \\
\mathrm{n}=15\end{array}$ \\
$\%$
\end{tabular}} & \multirow{2}{*}{\begin{tabular}{|r}
$\begin{array}{c}\text { Total } \\
\mathrm{n}=51\end{array}$ \\
$\%$
\end{tabular}} \\
\hline \multirow{4}{*}{ Age group } & & & & & & & \\
\hline & 35 years or less & 42.80 & 6.60 & 50.00 & 25.00 & 53.303 & 35.30 \\
\hline & 36 to 50 years & 28.60 & 46.70 & 40.00 & 50.00 & 26.703 & 37.30 \\
\hline & 51 years or more & 28.60 & 46.70 & 10.00 & 25.00 & 20.002 & 27.40 \\
\hline \multirow[t]{3}{*}{ Education status } & No education & 28.6 & 13.3 & .0 & 50.0 & 33.3 & 21.6 \\
\hline & Primary to secondary education & 57.1 & 60.0 & 70.0 & 50.0 & 53.3 & 58.8 \\
\hline & Higher secondary and above & 14.3 & 26.7 & 30.0 & .0 & 13.4 & 19.6 \\
\hline \multirow[t]{3}{*}{ Years of farming experience } & 15 years or less & 71.4 & 13.4 & 50.0 & 100.0 & 20.0 & 37.3 \\
\hline & 16 to 30 years & 28.6 & 53.3 & 30.0 & .0 & 66.7 & 45.1 \\
\hline & More than 30 years & .0 & 33.3 & 20.0 & .0 & 13.3 & 17.6 \\
\hline \multirow[t]{3}{*}{ Main Income Source } & Dairy Farming & 14.3 & 33.3 & 10.0 & 25.0 & 60.0 & 33.4 \\
\hline & Agriculture & .0 & 6.7 & 50.0 & .0 & 6.7 & 13.7 \\
\hline & Others & 85.7 & 60.0 & 40.0 & 75.0 & 33.3 & 52.9 \\
\hline \multirow[t]{3}{*}{ Economic Status } & Poor (hand to mouth) & 42.9 & 60.0 & 30.0 & 75.0 & 26.7 & 43.1 \\
\hline & Middle Class (moderately solvent) & 57.1 & 13.3 & 10.0 & .0 & 33.3 & 23.5 \\
\hline & Rich ((solvent) & .0 & 26.7 & 60.0 & 25.0 & 40.0 & 33.3 \\
\hline \multirow[t]{3}{*}{ Family Members } & 1-5 Members & 42.9 & 53.3 & 30.0 & 75.0 & 33.3 & 43.1 \\
\hline & 6-10 Members & 57.1 & 26.7 & 60.0 & 25.0 & 46.7 & 43.1 \\
\hline & 10+ Members & .0 & 20.0 & 10.0 & .0 & 20.0 & 13.8 \\
\hline \multirow[t]{2}{*}{ Gender of the farmer } & Male & 71.4 & 86.7 & 100.0 & 50.0 & 100.0 & 88.2 \\
\hline & Female & 28.6 & 13.3 & .0 & 50.0 & .0 & 11.8 \\
\hline \multirow[t]{3}{*}{ House ownership } & Owned & 85.7 & 100.0 & 100.0 & 100.0 & 100.0 & 98.0 \\
\hline & Rented & 14.3 & .0 & .0 & .0 & .0 & 2.0 \\
\hline & Others & .0 & .0 & .0 & .0 & .0 & .0 \\
\hline $\begin{array}{l}\text { Dairy contribution to total } \\
\text { income }(\%)\end{array}$ & & 27.1 & 32.0 & 26.4 & 46.9 & 34.3 & 33.5 \\
\hline
\end{tabular}

Moreover, majority of the farm families are no more dependent on agricultural and or farming income sources. Though $60 \%$ and $33.3 \%$ of the smallholder farmers of Patiya and Hathazari are dependent on dairy farming as their main income source, only $10.0 \%, 14.3 \%$ and $25.0 \%$ of the farmers of Raojan, Sitakund and Boalkhali are dependent on the same source of income. The highest dairy income contributing Upazilla is Boalkhali (46.9\%) and the lowest dairy income contributing Upazilla is 
Raojan (26.4\%). In total, $52.9 \%$ of the peri-urban dairy farmers of the selected area rely on non-farming and non-agricultural sources for their income. Better education status (Table 1), less profitability (Table 3), unfair and unstable price, lack of financing opportunities (Table 5) market need gap and lack of market linkage (Table 6) might have contributed to the less reliability on farming and agriculture and to the moves to the other income sources. The education status statistics show $58.8 \%$ and $19.6 \%$ of the marginal farmers have 'primary to secondary education' and 'higher secondary and above' education respectively whereas $21.6 \%$ farmers have no formal education. According to other socio-economic characteristics, $43.1 \%$ of the farmers are living in poor condition though $98 \%$ of the farmers have their own house. Regarding gender, $88.2 \%$ of the peri-urban marginal farmers are male and majority of the farmers $(86.2 \%)$ have family members between 1 and 10 .

\section{Farm characterization}

Table 2 depicts the nine farm characteristics of the peri-urban marginal farmers of Chittagong Metro Area. In general, the majority portion of the peri-urban marginal farmers are not making profit though they keep continuing their dairy farming probably for maintaining family tradition. Regarding herd size and farm structure, most of the farmers $(54.9 \%)$ have 3 or fewer cattle and the same percentage of the farmers maintain mixed or semi-concrete farm structure. Semi-intensive farm management system is being used by $51 \%$ farmers. Although $64.7 \%$ of the farmers are getting the yearly production of milk below 1000 liters, the only exception is Patiya where $53.3 \%$ of the farmers are getting over 2000 liters yearly. Alam et al. (2011) also mentioned about such low productivity of the smallholder dairy farmers. A very significant percentage of the farmers $(94.1 \%)$ do not get any formal credit facilities. However, $100 \%$ of them get veterinary services which are government provided and very affordable. Though $66.7 \%$ farmers of the total area have local or indigenous breeds, the farmers of Patiya (73.3\%), a dairy zone of Chittagong District, have an exception of having HF Crossbred. Quite surprisingly, none of the farmers of the whole area keep any sorts of financial records. From the estimated data found from the survey, it is seen that $64.7 \%$ of the farmers are not making any profit being Sitakund in the top of the list $(85.7 \%)$. 
Table 2. Farm characteristics of the peri-urban marginal dairy farmers of CMA

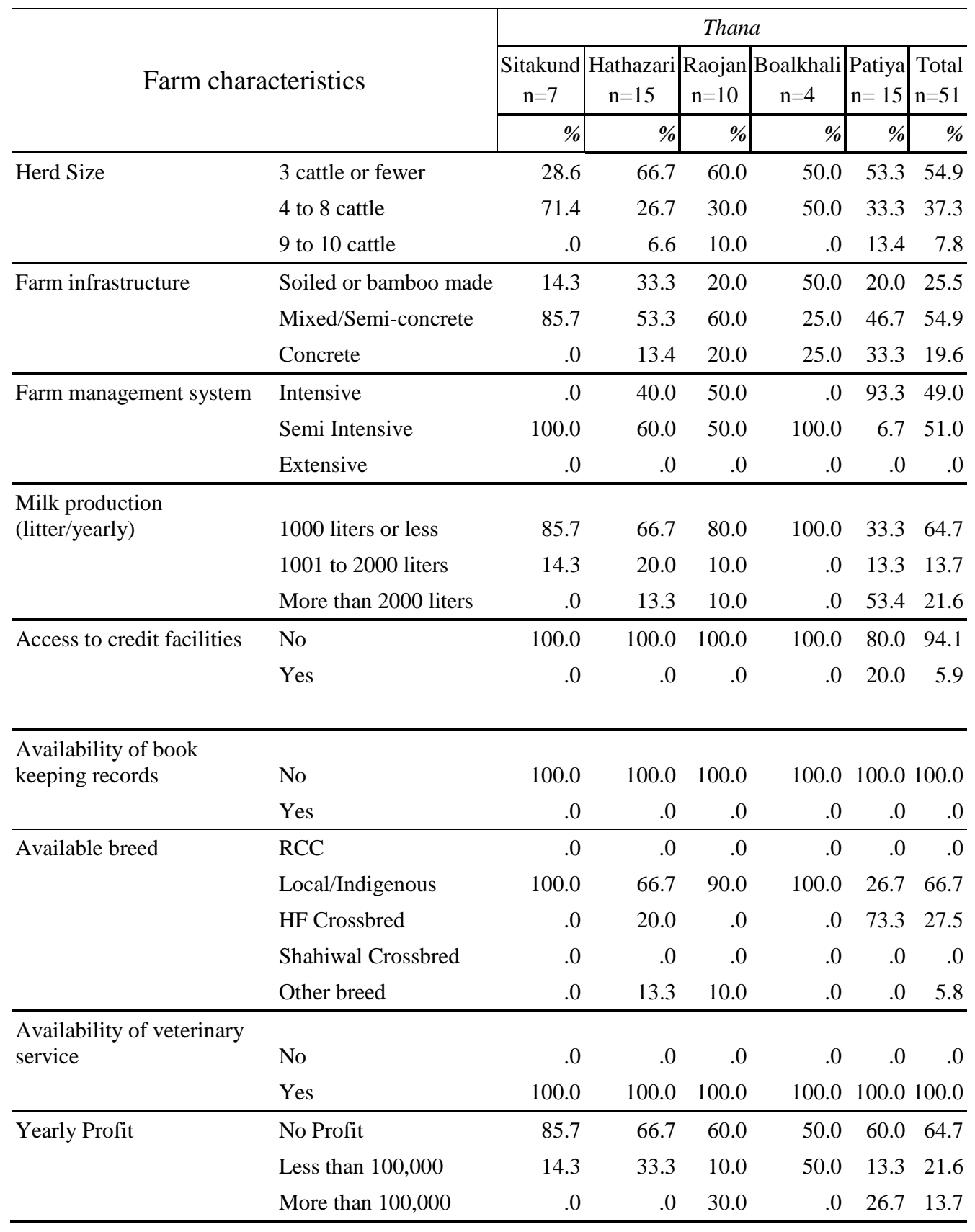


Profitability of the farms of the peri-urban areas have been exhibited in Table 3. It summarizes that the farmers of Sitakund, Hathazari are not profitable (ROI< $0 \%$ and BCR $<1)$ but there exists an opposite trend in Patiya and Raojan. To be specific, the marginal farmers of Sitakund and Hathazari are getting highly negative ROI of $(-59.1 \%)$ and $(-48.3 \%)$ respectively. On the contrary, Patiya farmers are getting better ROI which is $31.7 \%$. However, the farmers of Raojan and Boalkhali are making moderate ROI of $8.4 \%$ and $1 \%$ correspondingly. The BCR ratio is also denoting the non-profitability of Sitakund (0.75) and Hathazari (0.88) farmers. In total, the farmers of the whole area are earning ROI of only $2.8 \%$ and the BCR is 1.12 . But in a study (Huque et al., 2002) higher figures were found where the BCR was 1.32 and 1.45 for marginal and small farmers respectively. These differences might originate from the course of time and also due to the fact that the profitability is decreasing.

Table 3. Profitability Analysis

\begin{tabular}{l|c|c|c|c|c|c}
\multicolumn{1}{c}{ Particulars (Yearly) } & $\begin{array}{c}\text { Sitakund } \\
\text { Taka }\end{array}$ & $\begin{array}{c}\text { Hathazari } \\
\text { Taka }\end{array}$ & $\begin{array}{c}\text { Raojan } \\
\text { Taka }\end{array}$ & $\begin{array}{c}\text { Boalkhali } \\
\text { Taka }\end{array}$ & $\begin{array}{c}\text { Patiya } \\
\text { Taka }\end{array}$ & $\begin{array}{c}\text { Total } \\
\text { Taka }\end{array}$ \\
\hline Investment in housing & $20,571.0$ & $46,733.0$ & $92,700.0$ & $21,250.0$ & $59,800.0$ & $54,000.0$ \\
Investment in cattle & $32,857.0$ & $56,100.0$ & $426,950.0$ & $6,250.0$ & $110,400.0$ & $137,686.0$ \\
Investment in others & $2,093.0$ & - & 500.0 & $1,025.0$ & 793.0 & 699.0 \\
A. Investment- Total & $55,521.0$ & $102,833.0$ & $520,150.0$ & $28,525.0$ & $170,993.0$ & $192,385.0$ \\
\hline Milk sales & $20,907.0$ & $37,383.0$ & $31,440.0$ & $31,838.0$ & $168,767.0$ & $72,164.0$ \\
Calf sales & $15,000.0$ & $38,833.0$ & $144,500.0$ & $1,250.0$ & $68,733.0$ & $62,127.0$ \\
Cow-dung sales & $26,914.0$ & - & - & $12,000.0$ & 800.0 & $4,871.0$ \\
Home consumption of milk & $6,336.0$ & $10,837.0$ & $8,970.0$ & $6,862.0$ & $11,585.0$ & $9,761.0$ \\
B. Revenue- Total & $69,157.0$ & $87,053.0$ & $184,910.0$ & $51,950.0$ & $249,885.0$ & $148,923.0$ \\
\hline Cost of feeding & $84,471.0$ & $88,208.0$ & $123,918.0$ & $44,530.0$ & $165,053.0$ & $113,873.0$ \\
Cost of medication and vaccines & $14,800.0$ & $13,667.0$ & $10,500.0$ & $4,625.0$ & $20,467.0$ & $14,492.0$ \\
Cost of Artificial Insemination $(\mathrm{AI})$ & 817.0 & 503.0 & 810.0 & 875.0 & 723.0 & 700.0 \\
Cost of labor & - & $31,989.0$ & $2,527.0$ & - & $3,733.0$ & $11,002.0$ \\
Cost of damage/wastage & $1,886.0$ & $2,400.0$ & $3,600.0$ & $1,500.0$ & $5,760.0$ & $3,482.0$ \\
C. Cost- Total & $101,974.0$ & $136,768.0$ & $141,354.0$ & $51,530.0$ & $195,736.0$ & $143,550.0$ \\
\hline D. Profit- Total $(B$-C) & $(32,817.00)$ & $(49,714.00)$ & $43,556.00$ & 420.00 & $54,149.00$ & $5,373.00$ \\
\hline E. BCR (B/C) & 0.75 & 0.88 & 1.63 & 1.00 & 1.22 & 1.12 \\
\hline F. Return on Investment \% (D/A) & $-59.1 \%$ & $-48.3 \%$ & $8.4 \%$ & $1.5 \%$ & $31.7 \%$ & $2.8 \%$ \\
\hline
\end{tabular}

Poor condition of the farm family, very little credit facilities and less profitability might hinder them to increase the herd size and milk production and also to introduce high-yielding breeds. It might also indicate they are simply losing their interest in dairy farming. 


\section{Technological characterization}

Table 4. Technological characteristics of the peri-urban marginal dairy farmers of CMA

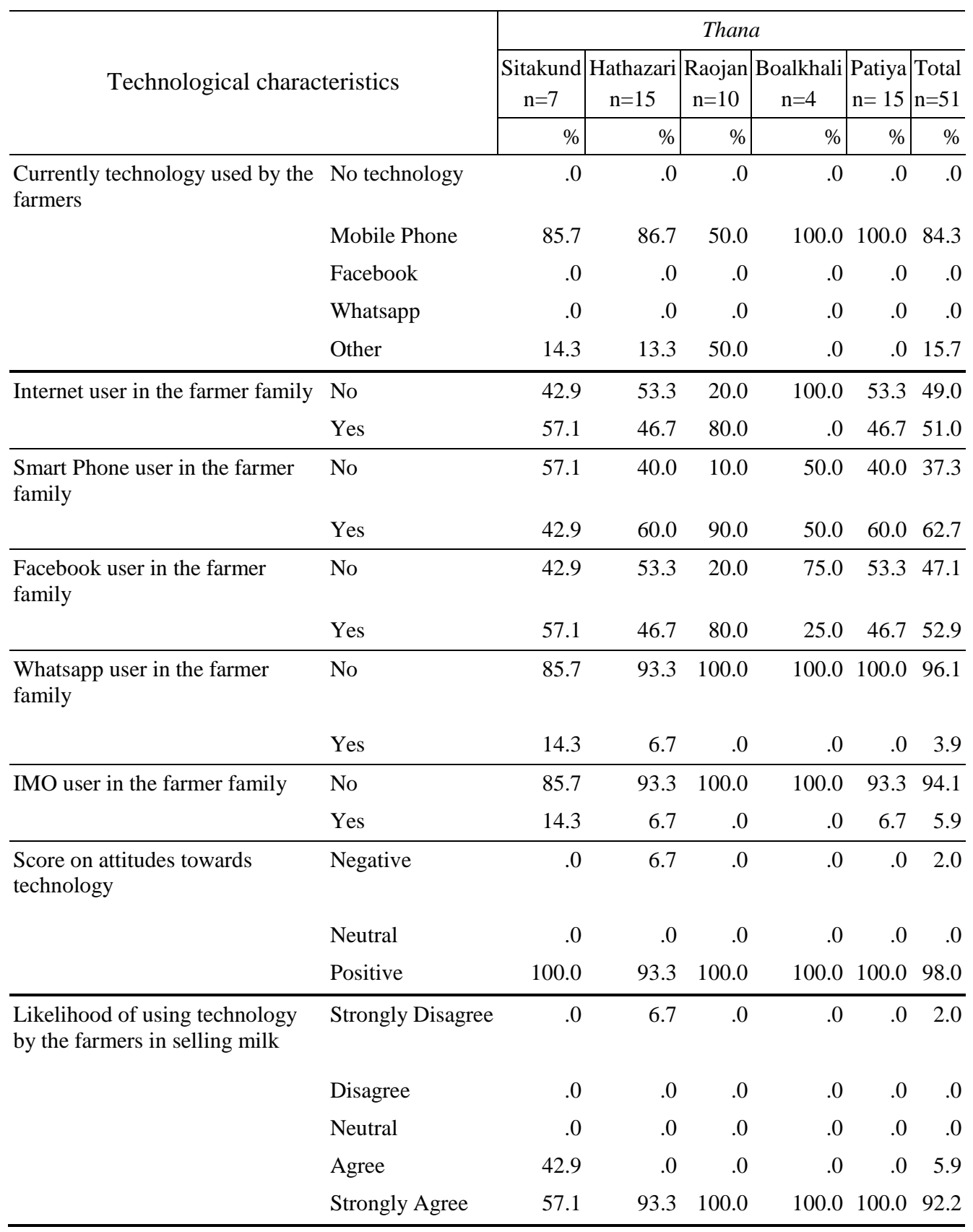


Table 4 demonstrates the technological characteristics of the marginal dairy farmers of the study area. It shows that the farmers and their family have experienced the touch of use of communication technology. Very fascinatingly, $62.7 \%, 52.9 \%$ and $51.0 \%$ of the farmer families have smartphone, facebook and internet users in their families respectively. The least percentage of the farmer families are exposed to WhatsApp (3.9\%) and IMO (5.9\%) mobile communication application. However, $84.3 \%$ of the farmers themselves use mobile phone for communication purpose. Most importantly, the farmers (98\%) have positive attitude towards use of technology. Such positive attitude towards technology and adoption of trending technology is a very good sign for future development of the community as technology is being capitalized in different sectoral development. Abdi et al. (2017) emphasized the use of different ICT platforms in publicizing agricultural market information to the farmers to enable them to access to information of markets for the products, market price, input price and weather forecast. In this connection, the peri-urban marginal dairy farmers' insight regarding the current technological ability and their positive attitude towards technology could be used as input in formulating future development program for the community.

\section{Problems faced by the farmers}

The study also attempted to pin point the problems faced by the farmers (Table 5). The data was taken in Likert scale where 1 denotes to Strongly Disagree and 5 refers to Strongly Agree. Table 5 says most of the farmers highlighted three problems: finance (mean: 4.53), unstable price (mean: 4.27) and unfair price (mean: 4.00) of the milk. The marginal farmers do not have access to formal credit facilities and they become helpless to get adequate capital supply (Quddus, 2018). Regarding unfair price, Table 7 demonstrates the highest price is 75.00 tk./liter paid by Consumer/Household customers in urban area but from the field survey, it has been found that the farmers get the lowest price (Tk. 40/liter) in Patiya and Hathazari and the mean price of the whole area is Tk. 53.65/liter (Table 8) Quddus (2018) also found that low price of the milk is a constraint for the smallholders. However, comparing Table 7 and Table 8 , it is clear that there is a better opportunity for the peri-urban marginal farmers in the urban consumer market and currently they are getting lesser price of milk. Furthermore, the study attempted to know the farmers' thoughts regarding the reasons for not getting the fair price. The farmers reported the main causes: lack of value addition (mean 4.12), lack of storage facilities (mean 4.02), market need gap (mean 3.18) and lack of market linkage (mean 3.02) (Table 6). Shantana R and Proloy (2003) also reported that dairy farmers are facing marketing and storage issues in Bangladesh. 
Table 5. Problems faced by the farmers

\begin{tabular}{lcccccc}
\hline & Minimum & Maximum & Mean & Std. Deviation & Rank \\
\hline Farmers lack finance & 1 & 5 & 4.53 & 1.12 & 1 \\
Farmers face unstable price of the milk & 1 & 5 & 4.27 & 1.218 & 2 \\
Farmers get unfair price of the milk & 1 & 5 & 4.00 & 1.166 & 3 \\
Farmers lack storage facilities & 1 & 5 & 3.94 & 1.448 & 4 \\
Farmers can't pack the milk & 1 & 5 & 3.51 & 1.206 & 5 \\
Farmers lack transportation & 1 & 5 & 3.35 & 1.197 & 6 \\
Farmers lack market linkage & 1 & 5 & 3.02 & 1.086 & 7 \\
Farmers feel gap with the consumer & 1 & 5 & 2.59 & 1.023 & 8 \\
Farmers lack market information & 1 & 5 & 2.47 & 1.189 & 9 \\
\hline
\end{tabular}

Table 6. Reasons for Unfair Price (Measured in Likert scale)

\begin{tabular}{|c|c|c|c|c|c|}
\hline & & $\mathrm{N}$ & Mean & Std. Deviation & Std. Error \\
\hline \multirow{6}{*}{$\begin{array}{l}\text { Farmers not getting fair price due to lack of } \\
\text { market info }\end{array}$} & Sitakund & 7 & 3 & 1 & 0.378 \\
\hline & Hathazari & 15 & 2.33 & 1.291 & 0.333 \\
\hline & Raojan & 10 & 2.4 & 0.699 & 0.221 \\
\hline & Boalkhali & & 2 & 1.414 & 0.707 \\
\hline & Patiya & 15 & 2.27 & 1.163 & 0.3 \\
\hline & Total & 51 & 2.39 & 1.115 & 0.156 \\
\hline \multirow{6}{*}{$\begin{array}{l}\text { Farmers not getting fair price due to lack of } \\
\text { market linkage }\end{array}$} & Sitakund & 7 & 3.14 & 1.069 & 0.404 \\
\hline & Hathazari & 15 & 2.93 & 1.1 & 0.284 \\
\hline & Raojan & 10 & 2.4 & 0.699 & 0.221 \\
\hline & Boalkhali & 4 & 4 & 0 & 0 \\
\hline & Patiya & 15 & 3.2 & 1.207 & 0.312 \\
\hline & Total & 51 & 3.02 & 1.068 & 0.149 \\
\hline \multirow{6}{*}{$\begin{array}{l}\text { Farmers not getting fair price due to market } \\
\text { need gap }\end{array}$} & Sitakund & 7 & 2.14 & 0.9 & 0.34 \\
\hline & Hathazari & 15 & 3.07 & 0.704 & 0.182 \\
\hline & Raojan & 10 & 3.9 & 0.316 & 0.1 \\
\hline & Boalkhali & 4 & 3 & 0.816 & 0.408 \\
\hline & Patiya & 15 & 3.33 & 1.047 & 0.27 \\
\hline & Total & 51 & 3.18 & 0.932 & 0.13 \\
\hline \multirow{3}{*}{$\begin{array}{l}\text { Farmers not getting fair price due to lack of } \\
\text { customer trust }\end{array}$} & Sitakund & 7 & 2.14 & 1.345 & 0.508 \\
\hline & Hathazari & 15 & 3.33 & 1.047 & 0.27 \\
\hline & Raojan & 10 & 3 & 0.667 & 0.211 \\
\hline
\end{tabular}




\begin{tabular}{|c|c|c|c|c|c|}
\hline & & $\mathrm{N}$ & Mean & Std. Deviation & Std. Error \\
\hline & Boalkhali & 4 & 1 & 0 & 0 \\
\hline & Patiya & 15 & 2.33 & 1.952 & 0.504 \\
\hline & Total & 51 & 2.63 & 1.455 & 0.204 \\
\hline \multirow{6}{*}{$\begin{array}{l}\text { Farmers not getting fair price due to lack of } \\
\text { value addition }\end{array}$} & Sitakund & 7 & 2.86 & 1.464 & 0.553 \\
\hline & Hathazari & 15 & 3.93 & 1.1 & 0.284 \\
\hline & Raojan & 10 & 4.1 & 0.316 & 0.1 \\
\hline & Boalkhali & 4 & 4 & 0 & 0 \\
\hline & Patiya & 15 & 4.93 & 0.258 & 0.067 \\
\hline & Total & 51 & 4.12 & 1.032 & 0.145 \\
\hline \multirow{6}{*}{$\begin{array}{l}\text { Farmers not getting fair price due to lack of } \\
\text { storage facilities }\end{array}$} & Sitakund & 7 & 3.57 & 1.813 & 0.685 \\
\hline & Hathazari & 15 & 4.67 & 1.047 & 0.27 \\
\hline & Raojan & 10 & 4 & 1.633 & 0.516 \\
\hline & Boalkhali & 4 & 4 & 2 & 1 \\
\hline & Patiya & 15 & 3.6 & 1.404 & 0.363 \\
\hline & Total & 51 & 4.02 & 1.476 & 0.207 \\
\hline
\end{tabular}

Table 7. Average purchase price of the buyers

\begin{tabular}{lc|c}
\hline \multicolumn{1}{c|}{ Different Buyers } & $\begin{array}{c}\text { Count of Buyer } \\
\text { Category }\end{array}$ & $\begin{array}{c}\text { Average of Purchase } \\
\text { Price (Taka) }\end{array}$ \\
\hline Local Market & 41 & \\
Bulk Buyer (Big)-Purchase 100 Liters+ & 2 & 52.50 \\
Bulk Buyer (Medium)-Purchase 51-100 Liters & 3 & 63.33 \\
Bulk Buyer (Small)-Purchase 10-50 Liters & 14 & 59.79 \\
Door to Door Delivery/Consumer/Household & 14 & 66.07 \\
Local Village Bazaar & 6 & 56.50 \\
Others & 2 & 57.50 \\
\hline Urban Market & 16 & \\
Bulk Buyer (Big)-Purchase 100 Liters+ & 1 & 45.00 \\
Bulk Buyer (Small)-Purchase 10-50 Liters & 4 & 53.75 \\
Door to Door Delivery/Consumer/Household & 10 & 75.00 \\
Local Urban Bazaar & 1 & 55 \\
\hline
\end{tabular}


Table 8 . Net price received by the farmers

\begin{tabular}{lrrrrrr}
\hline & \multicolumn{5}{c}{ Thana } \\
& $\begin{array}{l}\text { Sitakund } \\
\text { Tk/Liter }\end{array}$ & $\begin{array}{r}\text { Hathazari } \\
\text { Tk/Liter }\end{array}$ & $\begin{array}{r}\text { Raojan } \\
\text { Tk/Liter }\end{array}$ & $\begin{array}{r}\text { Boalkhali } \\
\text { Tk/Liter }\end{array}$ & $\begin{array}{r}\text { Patiya } \\
\text { Tk/Liter }\end{array}$ & $\begin{array}{r}\text { Total } \\
\text { Tk/Liter }\end{array}$ \\
\hline Mean & 62.86 & 49 & 59 & 60 & 48.73 & 53.65 \\
Maximum & 70 & 70 & 60 & 60 & 60 & 70.00 \\
Minimum & 50 & 40 & 50 & 60 & 40 & 40.00 \\
\hline
\end{tabular}

\section{CONCLUSION}

The research demonstrates the salient socio-economic, farm and technological characteristics of the peri-urban marginal dairy farmers of Chittagong Metro Area. Most of the farms are found to be in 'no profit' category. Unfair and unstable prices, poor financing opportunities, market need gap, lack of market linkage, storage facilities and value addition are found as major issues in the study area. The study output might help the future formulation of development program for the small and marginal dairy farmers' community.

\section{ACKNOWLEDGEMENT}

The authors thank all the farmers who participated in the study, for their hospitality and full support. Finally, they like to pay the gratitude to Chittagong Veterinary and Animal Sciences University (CVASU) and University Grants Commission (UGC) for providing the necessary funds.

\section{REFERENCES}

Abdi, H., Jacob W.W., and Chesambu, N.A. (2017). Type of Information and Communication Technology Tools Used in Dissemination of Agricultural Market Information to Vegetable Farmers in Vihiga County, Kenya. International Journal of Management Research \& Review, 7 (7), 997-1005.

Alam, A., Ahmed, A., Quisumbing R.A., Hassan, Z., and Zobair, M. (2011). The Dairy Value Chain Project In Bangladesh: Midterm Report. Retrieved December 23, 2018 from http://www.carebangladesh.org/publication/Publication_5093098.pdf.

Bangladesh Investment Development Authority (BIDA). (2010). Dairy in Bangladesh. Retrieved December 23, 2018 from www.bida.gov.bd

Espinoza-Ortega, A., Espinosa-Ayala, E., Bastida-López, J., Castañeda-Martínez, T., and Arriaga-Jordán, C.M. (2007). Small-scale dairy farming in the highlands of Central Mexico: Technical, economic and social aspects and their impact on poverty. Experimental Agriculture, 43 (2), 241-256.

Fischer, E., and Qaim, M. (2012). Linking Smallholders to Markets: Determinants and Impacts of Farmer Collective Action in Kenya. World Development, 40(6), 1255-1268. 
Flaten, O. (2002). Alternative rates of structural change in Norwegian dairy farming: Impacts on costs of production and rural employment. Journal of Rural Studies, 18(4), 429-441.

García, C.G.M., Dorward, P. and Rehman, T. (2012). Farm and socio-economic characteristics of smallholder milk producers and their influence on technology adoption in Central Mexico. Tropical Animal Health and Production, 44 (6), 11991211.

Gizaw, S., Abera, M., Muluye, M., Aliy, M., and Alemayehu, K. (2017). Validating the Classification of Smallholder Dairy Farming Systems Based on Herd Genetic Structure and Access to Breeding Services. Agricultural Sciences, 8(7), 545-558.

Heady, E.O. and Sonka, S.T. (1974). Farm Size, Rural Community Income, and Consumer Welfare. American Journal of Agricultural Economics, 56 (3), 534.

Hemme, T., Garcia, O., and Khan, A.R. (2004). A Review of Milk Production in Bangladesh with Particular Emphasis on Small-Scale Producers. Retrieved December 21, 2018 from http://www.fao.org/3/a-bp227e.pdf.

Holloway, G., Nicholson, C., Delgado, C., Staal, S., and Ehui, S. (2000). Agroindustrialization through institutional innovation transaction costs, cooperatives and milk-market development in the east-African highlands. Agricultural Economics, 40(6), 1255-1268.

Huque, K.S., Rahman, M.M., and Islam, M. (2002). Farming characteristics of cooperative dairy production systems in Bangladesh. Bangladesh Journal of Livestock Research, 9 , 17-29.

Huque, K.S. (2011). A performance profile of dairying in Bangladesh - programs, policies and way forwards.. Bangladesh Journal of Animal Science, 43(2), 81-103.

Kabir, M.H. and Talukder, R.K. (1999). Economics of Small Scale Dairy Farming in Bangladesh under the Government Support Programme. Asian-Australasian Journal of Animal Sciences, 12 (3), 429-434.

Kirui, O.K., and Njiraini, G.W. (2013). Determinants of agricultural commercialization among the rural poor: The role of ICT and collective action initiatives and gender perspective in Kenya. Paper Prepared for the 4th Conference of AAAE, Diar Lemdina Hotel-Hammamet, Tunisia, 22-23 September, 2013. 1747-1754

McDonald, R., Shalloo, L., Pierce, K., and Horan, B. (2013). Evaluating expansion strategies for startup European Union dairy farm businesses. Journal of Dairy Science, 96, 40594069.

Meskel, K.G. and Gemechu, A. (2017). Comparative Cost Benefit Analysis of Dairy and Cereal Crops Production with Special References to Tef and Wheat Crops: A Case Study of Adea and Lume Districts of East Shoa Zone, Ethiopia. Journal of Agriculture and Environmental Science, 17 (5), 440-449.

Pérez Urdiales, M., Lansink, A.O., and Wall, A. (2015). Eco-efficiency Among Dairy Farmers: The Importance of Socio-economic Characteristics and Farmer Attitudes. Environmental and Resource Economics, 64 (4), 559-574.

Quddus, M.A. (2018). Smallholder Dairy Farming in Bangladesh: A Socioeconomic Analysis. Bangladesh Journal of Agricultural Economics, 37 (1-2), 1-25. 
Van Schaik, G., Perry, B.D., Mukhebi, A.W., Gitau, G.K., and Dijkhuizen, A.A. (1996). An economic study of smallholder dairy farms in Murang'a District, Kenya. Preventive Veterinary Medicine, 29 (1), 21-36

Shantana, R.H., and Proloy, B. (2003). Dairy Production, Consumption and Marketing in Bangladesh. Retrieved December 23, 2018 from http://research.brac.net/new/ebook/ Publication/21-Dairy-production-consumption-and-marketing-in-Bangladesh\#page/2.

Somda, J., Kamuanga, M., and Tollens, E. (2005). Characteristics and economic viability of milk production in the smallholder farming systems in The Gambia. Agricultural Systems, 85 (1), $42-58$

Uddin, M.N., Uddin, M.B., Al Mamun, M., and Hassan, M.M. (2012). Small Scale Dairy Farming for Livelihoods of Rural Farmers: Constraint and Prospect in Bangladesh. Journal of Animal Science Advances, 2(6), 543-550.

UNB. (2017). The Asian Age. Dairy farmers look for milk marketing scope. The Asian Age Online, Bangladesh, Retrieved February 28, 2018 from https://dailyasianage.com/ news /64117/dairy-farmers-look-for--milk-marketing-scope.

UNB. (2016). Bangladesh Dairy: Challenges and Opportunities. The Daily Star, Retrieved April 21, 2018 from https://www.thedailystar.net/round-tables/bangladesh-dairychallenges-and-opportunities-1337251. 